\title{
Model for assessing the competitiveness of rural areas in the region in the new economic conditions
}

\author{
Svetlana Podgorskaya ${ }^{1, *}$ and Sergei Schitov ${ }^{1}$ \\ ${ }^{1}$ Federal State budget scientific institution, 344006, Rostov-on-Don, Chekhov Ave., 41, Rostov re- \\ gion, Russian Federation
}

\begin{abstract}
A model for assessing the competitiveness of rural areas in the region has been developed, which allows analyzing the parameters of the actual socio-economic situation on the basis of statistical data and expert assessments in order to make management decisions aimed at leveling and mitigating the consequences of crisis phenomena. The system of indicative indicators for assessing the main areas of rural life: economic, institutional, innovative, social, labor, and environmental. The integral indicator of the competitiveness of rural areas based on an assessment of the extent to which the characteristic levels of performance target values, the position of the state management and key customers. To calculate the indicator, we used the multivariate average method, which generalizes the levels of characteristics of the studied sample in order to further rank the elements. The weight coefficients for each component of the model were determined by the expert assessment method based on a survey of respondents - rural residents and experts in the field of rural development. The results of testing the model on the materials of rural areas of the Rostov region are presented.
\end{abstract}

\section{Introduction}

Today, the economic community is actively discussing the development of global and national economies in the new economic conditions, which are defined as a special stage or a new development paradigm. There are various theoretical and methodological approaches that to some extent note its main characteristics, such as: low rates of economic growth; lower prices for oil resources; high volatility in the commodity and money markets; high unemployment; reduced effectiveness of state economic policy; reducing the role of leading countries in the global economy.

Experts note that the current changes are not a temporary phenomenon, traditional tools for restoring growth will not be enough, new approaches, institutions and mechanisms are needed that will ensure innovative growth of the national economy and increase its competitiveness in the global and domestic markets.

\footnotetext{
*Corresponding author: svetlana.podgorskaya@gmail.com
} 
In the new economic conditions, external destabilizing factors are superimposed on existing internal contradictions in the development of rural territories and the domestic agricultural economy, leading to a so-called synergetic effect, increasing the instability of socio-economic systems at all levels of administrative-territorial entities and organizational and legal forms of management.

Theoretical and methodological studies of a new model of rural development based on the principles of endogenous development have been widely recognized and developed in world science. This approach assumes socio-economic development of rural areas based on internal resources - natural, human and cultural [1,2].

Despite the fact that the category of competitiveness has long been fully represented in the scientific works of domestic and foreign scientists, it mainly concerns the essential characteristics at the level of technologies, products, firms, organizations. The territorial (spatial) aspect of this scientific definition is not fully understood and is considered mainly at the level of the region and the country as a whole.

Research on the competitiveness of rural territories in the Russian scientific literature is rare and fragmentary. within the framework of the tasks being solved, they mainly relate to the description of its constituent elements (the level of development of the agro-industrial complex, agricultural production, social sphere, human capital) [3, 4]. At the same time, I would like to note the publication of S. N. Semenov and V. N. Rubtsova [5], in which the authors on the basis of a systematic approach consider the competitive and sustainable development of agriculture and rural areas on the basis of a balanced socio-natural and economic space.

Spatial development in the context of socio-economic, innovative, and informational transformations is closely related to the formation of competitive advantages created for the effective use of available resources. Competitive advantages make rural areas attractive for investors, entrepreneurs, qualified personnel, etc., which directly or indirectly affect the level of rural development.

Investment and labor resources "migrate" to the most attractive and competitive regions. In this regard, it is important to identify the factors that determine the competitiveness of rural areas in the region and its quantitative and qualitative assessment for comparative analysis and management.

\section{Research methodology}

Depending on the goals set, a methodological approach is formed in each specific case, which determines the parameters for assessing the competitiveness of the system under study [6].

A review of methodological approaches to calculating and evaluating the competitiveness of rural areas has shown that today there is no consensus among Russian and foreign scientists on this issue. There are a large number of author's methods, mainly differing in a set of indicators that allow you to assess the competitiveness of rural areas in various areas of life-supporting subsystems, and determine the factors that affect their position in comparison. Approaches also differ in the set of mathematical apparatus within a particular methodology.

The presented model for assessing the competitiveness of rural territories is based on the method of calculating the integral indicator of regional competitiveness and includes significant indicators of the main spheres of rural life. In order to study the formation of the competitiveness of rural territories in the new economic conditions, the model includes such indicators as innovation activity, the level of digitalization of the agro-industrial complex, and the development of the institutional environment. 
A significant constraint in the formation of the system of indicators of the model was the current state of regional statistics of rural territories, which does not meet the growing need for it in quantitative and qualitative terms. To assess the indicator of the level of development of the institutional environment in rural areas, we used the method of expert assessments and questionnaires.

As a result, a set of key blocks of rural territories competitiveness was formed (figure $1)$.

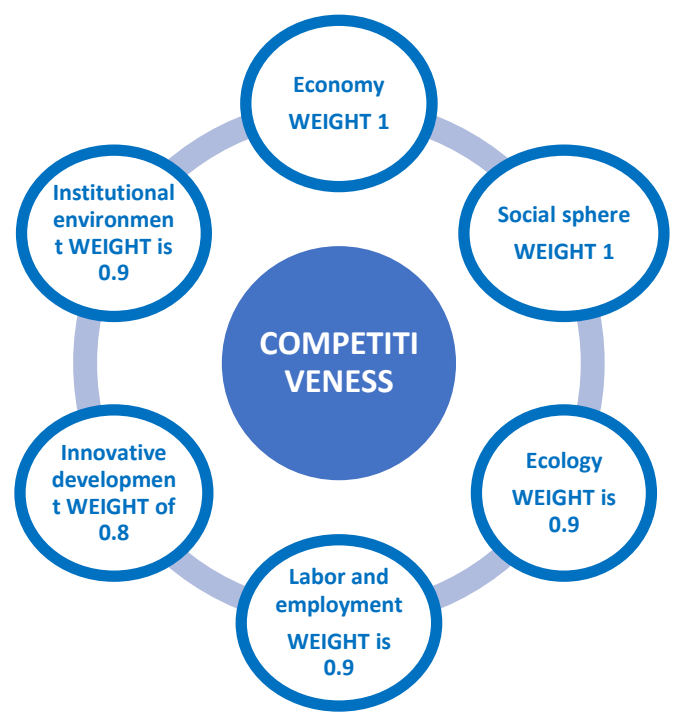

Fig. 1. Main elements of competitiveness of rural territories in the region

Note: developed by the authors

Weight values for each of the spheres of life in rural areas were determined by the method of expert assessment based on a survey of respondents of the corresponding competencies.

Depending on the research goals, the model can be supplemented with a number of indicators.

Since expert assessments were used to build the model, the degree of consistency of expert opinions was determined based on the concordance coefficient or the Kendall rank correlation coefficient using the formula:

$$
W C=\frac{12 \sum_{i=1}^{n}\left(\sum_{j=1}^{m} X i j\right) 2-\frac{\sum_{i=1}^{n}\left(\sum_{j=1}^{m} X i j\right) 2}{N}}{M^{2}\left(N^{3}-N\right)}
$$

where $N$ is the number of indicators evaluated by several experts;

$M$ - number of experts;

$x_{i j}$ - evaluation of the $\mathrm{i}$-th indicator by the $\mathrm{j}$-th expert.

The $W c$ coefficient can take values from 0 to 1 . if the value exceeds 0.5 , the expert opinions are considered to be consistent. In our case, the concordance coefficient is 0.7 .

The proposed integral indicator is based on an assessment of the degree of compliance of the actual values of the characteristics of the object of research with the desired values from the point of view of the state or consumers (average figures for the Russian Federation or the district). Normative (threshold) or recommended (normal) values are given as reference values in the process of assessing the region's competitiveness.

The convergence coefficient of the $i$-th indicator is calculated using the formula: 


$$
V_{i}=\frac{E_{i}}{F_{i}}
$$

where $E_{i}$ is the reference (threshold) value of the selected indicator;

$F_{i}$ - the actual value of the indicator.

At the same time, if consumers (the state) are interested in maximizing the criterion, the convergence coefficient was defined as the ratio of the actual value and the threshold (optimal) value. If the situation dictates the need to contain the manifestations or strengthening of negative trends, the convergence coefficient was defined as the ratio of the threshold (optimal) value and the actual level [7].

To obtain an integral indicator of competitiveness assessment, we use the multidimensional average method, which generalizes the levels of characteristics of the sample under study in order to further rank the elements:

$$
Q=\sum W_{j} * V_{i}
$$

where: Q - is an integral measure of competitiveness

$W j$ - weight of the $j$-th sphere of life in rural areas,

$V i$ - convergence coefficient of the $i$-th indicator.

In accordance with the efficiency scale, the level of competitiveness of rural territories in the region is determined:

$\mathrm{Q}=1-2-$ low level of competitiveness;

$\mathrm{Q}=3-4$ - average level of competitiveness;

$\mathrm{Q}=5-6$ - the level of competitiveness is high.

According to the methodology, regions with an average or below-average level of competitiveness need more extensive state support due to poor infrastructure, poor quality of life (insufficient provision of social infrastructure), and the need for financial resources for the development of the social sphere and economy.

The presented methodological approach allows us to calculate the level of competitiveness of rural territories not only in dynamics over the years to identify the impact of factors acting on the indicator, but also to conduct a comparative characteristic in regional or municipal aspects.

\section{Results}

The concept of competitiveness is a fundamental category of economic science, which is considered as a multi-level characteristic depending on the purpose and subject of research.

The competitiveness of rural areas is an integral part of the region's competitiveness and largely determines it. At the same time, its formation has specific features due to the characteristics of the rural socio-economic and cultural environment, is determined by the institutional, environmental, functional and administrative-economic features of their territorial development. The main such signs are the low-diversified industrial structure of the rural economy, low sensitivity to innovation due to the distance from scientific and technical centers, limited reproduction of labor resources, low migration inflow, and low development of rural social networks.

The competitiveness of rural territories should be considered in the synergetic unity and interaction of their potential and institutional conditions for its implementation. Since rural territories differ in their available potential, including climatic conditions, the availability of natural resources, and the conditions for conducting economic activities, forms of their development differ in terms of competitive advantages.

Forming the competitiveness of a rural territory is the organization of the socio- 
economic space of the village in such a way as to ensure the maximum conversion of available resources (potential) into economic and social effect (capital), while maintaining ecological balance and ensuring an improvement in the quality of life of the rural population.

From the standpoint of the indicated approach subsystems of rural areas were structured by the types of activities they cover, with its institutional specificity and are present in the model blocks: social, economic, environmental, innovative.

The main part of the indicators was calculated on the basis of state statistics. The level of development of the institutional environment was determined by the expert method, based on a survey of the rural population and specialists in the field of socio-economic development of the village in the range of the qualitative assessment scale (table 1). Respondents were asked to assess the quality of state management of rural development, the activities of local self-government bodies, the work of public associations, and the level of public-private partnership.

Table 1. Scale of formalization of expert assessments

\begin{tabular}{|l|c|c|c|c|c|c|c|}
\hline $\begin{array}{l}\text { Qualitative } \\
\text { assessment }\end{array}$ & very low & low & $\begin{array}{c}\text { below the } \\
\text { average }\end{array}$ & average & $\begin{array}{c}\text { above the } \\
\text { average }\end{array}$ & high & very high \\
\hline $\begin{array}{l}\text { The range of } \\
\text { scoring }\end{array}$ & 0,1 & $0,2-0,3$ & 0,4 & $0,5-0,6$ & 0,7 & $0,8-0,9$ & 1,0 \\
\hline
\end{tabular}

Depending on the research goals, the model can be supplemented with a number of indicators.in particular, it is interesting to compare indicators of scientific and professional educational potential as the main driver of innovative development of agriculture.

Testing of the model for assessing the competitiveness of rural areas in the region was carried out on the indicators of the Rostov region. In the authors ' opinion, the indicators included in the model most fully characterize the level of competitiveness of rural territories in the region in modern conditions and themselves are already reflectors of the effect of using the potential of the village. Based on the established criteria, calculations of indicators of convergence of the declared characteristics with normal (threshold) values were performed (table 2).

Table 2 - indicators for assessing the competitiveness of rural areas in the Rostov region in 2018.

\begin{tabular}{|c|l|c|c|c|}
\hline Indicator & \multicolumn{1}{|c|}{ Name of the indicator } & $\begin{array}{c}\text { Recommended } \\
\text { (normal) level }\end{array}$ & $\begin{array}{c}\text { Actual level in } \\
\text { RR }\end{array}$ & $\begin{array}{c}\text { Rapprochement, } \\
\text { \% }\end{array}$ \\
\hline 1 & \multicolumn{1}{c|}{2} & 3 & 4 & 5 \\
\hline $\mathrm{E}_{1}$ & $\begin{array}{l}\text { Agricultural products in actual } \\
\text { prices per capita of the rural popu- } \\
\text { lation, thousand rubles/person. }\end{array}$ & 151,36 & 189,12 & 124,95 \\
\hline $\mathrm{E}_{2}$ & $\begin{array}{l}\text { Profitability of goods, products } \\
\text { (works, services) sold) \% }\end{array}$ & 15,00 & 10,50 & 70,00 \\
\hline $\mathrm{E}_{3}$ & $\begin{array}{l}\text { Production per person employed in } \\
\text { agriculture, thousand rubles }\end{array}$ & 1548,45 & 1094,50 & 70,68 \\
\hline $\mathrm{I}_{1}$ & $\begin{array}{l}\text { Level of development of the institu- } \\
\text { tional environment }\end{array}$ & 1,00 & 0,70 & 70,00 \\
\hline $\mathrm{I}_{2}$ & $\begin{array}{l}\text { Competitiveness of agricultural } \\
\text { products, \% }\end{array}$ & 0,01 & 0,03 & 309,09 \\
\hline $\mathrm{I}_{3}$ & $\begin{array}{l}\text { Investment in fixed assets for agri- } \\
\text { cultural products, \% }\end{array}$ & 7,15 & 4,93 & 69,01 \\
\hline & $\begin{array}{l}\text { The share of small businesses in the } \\
\text { agricultural economy in terms of } \\
\text { production of goods and services, } \\
\text { \% }\end{array}$ & 32,50 & 27,79 & 85,50 \\
\hline $\mathrm{I}_{4}$ & & & \\
\hline
\end{tabular}

\begin{tabular}{|c|l|c|c|c|}
\hline 1 & \multicolumn{1}{|c|}{2} & 3 & 4 & 5 \\
\hline $\mathrm{Inn}_{1}$ & $\begin{array}{l}\text { Level of digitalization of the agro- } \\
\text { industrial complex, \% }\end{array}$ & 1,00 & 0,70 & 70,00 \\
\hline
\end{tabular}




\begin{tabular}{|c|c|c|c|c|}
\hline $\operatorname{Inn}_{2}$ & $\begin{array}{l}\text { Innovative activity of agricultural } \\
\text { enterprises, } \%\end{array}$ & 2,10 & 1,18 & 56,36 \\
\hline $\operatorname{Inn}_{3}$ & $\begin{array}{l}\text { Share of innovative products in } \\
\text { agricultural products shipped, } \%\end{array}$ & 1,90 & 0,02 & 1,05 \\
\hline $\operatorname{Inn}_{4}$ & $\begin{array}{l}\text { Percentage of managers and spe- } \\
\text { cialists with higher education, } \%\end{array}$ & 80,00 & 52,40 & 65,50 \\
\hline $\operatorname{Inn}_{5}$ & $\begin{array}{l}\text { Percentage of students enrolled in } \\
\text { programs for training qualified } \\
\text { workers in agriculture, } \%\end{array}$ & 20,00 & 10,66 & 53,31 \\
\hline $\mathrm{W}_{1}$ & $\begin{array}{l}\text { Percentage of the working-age } \\
\text { population, } \%\end{array}$ & 53,65 & 54,30 & 101,20 \\
\hline $\mathrm{W}_{2}$ & $\begin{array}{l}\text { The ratio of wages and the subsist- } \\
\text { ence minimum for the working-age } \\
\text { population, times }\end{array}$ & 2,10 & 2,58 & 123,03 \\
\hline $\mathrm{W}_{3}$ & $\begin{array}{l}\text { The ratio of wages of agricultural } \\
\text { workers to the average for the } \\
\text { economy in the region, } \%\end{array}$ & 80,00 & 60,81 & 76,02 \\
\hline $\mathrm{W}_{4}$ & $\begin{array}{l}\text { The unemployment rate in rural } \\
\text { areas, \% }\end{array}$ & 5,00 & 7,80 & 64,10 \\
\hline $\mathrm{S}_{1}$ & $\begin{array}{l}\text { Life expectancy of the rural popula- } \\
\text { tion, years }\end{array}$ & 71,67 & 72,43 & 101,06 \\
\hline $\mathrm{S}_{2}$ & $\begin{array}{l}\text { Provision of rural population with } \\
\text { comfortable housing, } \%\end{array}$ & 50,00 & 40,00 & 80,00 \\
\hline $\mathrm{S}_{3}$ & $\begin{array}{l}\text { Number of paramedic and midwife- } \\
\text { ry centers per } 1,000 \text { population }\end{array}$ & 0,89 & 0,76 & 85,33 \\
\hline $\mathrm{S}_{4}$ & $\begin{array}{l}\text { Provision of clean drinking water to } \\
\text { the population, } \%\end{array}$ & 66,40 & 63,50 & 95,63 \\
\hline $\mathrm{S}_{5}$ & $\begin{array}{l}\text { Level of gasification of houses } \\
\text { (apartments) in rural areas, } \%\end{array}$ & 60,30 & 63,80 & 105,80 \\
\hline $\operatorname{Eco}_{1}$ & $\begin{array}{l}\text { Percentage of soils exposed to } \\
\text { water and wind erosion, } \%\end{array}$ & 21,00 & 48,90 & 42,94 \\
\hline $\mathrm{EcO}_{2}$ & $\begin{array}{l}\text { Percentage of captured and neutral- } \\
\text { ized pollutants from stationary } \\
\text { sources of pollution, } \%\end{array}$ & 100,00 & 52,00 & 52,00 \\
\hline
\end{tabular}

Developed and calculated by the authors based on the source data [8]

The level of development of the agricultural sector in the region directly affects the formation and satisfaction of the basic needs of the rural population. Agricultural production is a traditional industry for most of the country and plays a crucial role in maintaining the standard of living and well-being of the population living in rural areas [9].

The conclusions of modern research show that the globalization of the economy, as an imperative of the dominant processes of the current period, has not reduced the importance of developing its own production, a special place in which agricultural products occupy [7, 10]. In this regard, the model includes indicators that reflect the competitiveness of the agricultural economy of the region.

The normal assessment limits for the economic component indicators are based on the values for the Krasnodar territory, which can be a benchmark for the level of agricultural development for the rest of the Russian Federation and is the main competitor of the Rostov region in the field of agricultural production. The exception is the level of profitability of agricultural production, which is set in accordance with the target indicator.

Since an effective institutional environment promotes a favorable investment climate, development of innovations, coordinated development of the social sphere of rural territories and innovative development of agriculture, and conservation of natural wealth, it is highlighted in the model as a separate block of indicators.

In addition to expert assessment of the level of development of the institutional environment, the model uses indirect indicators such as the share of small businesses in the agricultural economy, the competitiveness of agricultural products (the share of exports in 
shipped products), and investment in fixed assets.

In 2018, the Rostov region became the leader in exports of agricultural products, it amounted to 5.4 billion dollars, the nearest region, the Ivanovo region, lagged by $57 \%$ only 3.4 billion dollars, and the Krasnodar territory-2.6 billion dollars. The main share in the export structure is grain-73.1\%. by 2024, in accordance with the national project "Export of agricultural products", the Rostov region should export agricultural products worth $\$ 7.7$ billion. Due to the limited capacity of the transport and logistics infrastructure, emphasis will be placed on increasing the share of exports of processed products with high added value. Long-term concessional loans for the production of export-oriented products are planned as the main tools of state support in solving this problem, and restrictions on the commodity structure of exports are also discussed.

To ensure the competitiveness of the domestic agro-industrial complex in the new economic conditions, the introduction and development of innovations becomes critical [11]. Digitalization of agriculture is clearly defined as the main vector of innovative development of the agricultural sector [12]. In this regard, the innovative unit includes the indicator "Level of digitization APK", as well as indicators of innovative activity, level of qualification and assessment of personnel potential of the region as a share of students in the programmes of training skilled workers in agriculture.

Since there are no direct data available to assess the level of digitalization of agriculture in the region, the authors used the characteristics of the share of large and medium-sized farms using precision farming elements (in the Rostov region, according to the Ministry of agriculture and food, this indicator is $31 \%$ ), the share of equipment equipped with navigation equipment $(10 \%)$, the level of computerization and automation of production and technological processes at agricultural enterprises. In General, the level of use and implementation of digital technologies in the region is estimated as above average.

The most important indicator of the attractiveness of rural areas is the state of the labor sphere. In the model, it is estimated by such indicators as the share of the working-age population, the ratio of wages in agriculture and the subsistence minimum for the working-age population, the ratio of wages of agricultural workers to the average for the economy in the region, and the level of unemployment in rural areas.

As a normal (threshold) value of the ratio of remuneration for work in agriculture, the target value of the state program "Integrated development of rural territories" was adopted. The regional unemployment rate in rural areas was $7.8 \%$, and the recommended total unemployment rate according to the ILO methodology is $5 \%$.

The social block is represented by indicators that characterize the competitiveness of the social infrastructure in rural areas of the region. The presence of infrastructure that provides education and upbringing, as well as health maintenance, creates a sense of security and well-being of society.

It is empirically proved that the growth of human capital contributes to the increase of investment attractiveness of the subject, the development potential, imitation of advanced technologies, the level of trust in society, which in turn has a positive effect on the process of economic growth.

Life expectancy at birth can be considered a generalizing indicator of the quality of the social environment in rural areas. In the Rostov region, this indicator for rural areas in 2018 was higher than the average for Russia.

One of the priority conditions for the integrated development of rural areas is the sustainability of their natural environment, preservation and improvement of the ecological balance. The main subject and means of labor in agriculture are the land resources of the region. under the influence of anthropogenic impact, the agro-ecological state of the land and natural resources in General continues to deteriorate, which hinders the development of production and reduces the standard of living of the rural population [13]. 
One of the main sources of loss of the resource potential of soil fertility and reduced crop yields, deterioration and pollution of the environment is the degradation of agricultural land. In this regard, the environmental block includes an indicator of the quality of agricultural land for the spread of water and wind erosion. The threshold value is defined as the average value for the southern Federal district [14].

The second important indicator of the ecological block in the model is the level of atmospheric air pollution, defined as the proportion of captured and neutralized pollutants coming from stationary sources of pollution in rural areas. Municipal statistics show a very low value of this indicator.

An integral indicator was calculated for each sphere of life in rural areas (figure 2).

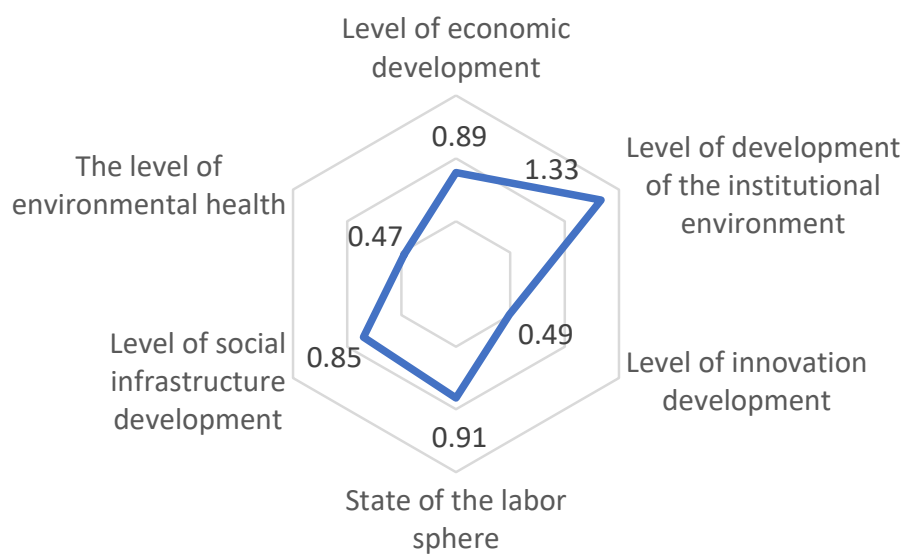

Fig. 2. Levels of development of rural areas.

Based on the calculated indicators of rural territories ' competitiveness, we will find an integral indicator:

$$
Q=1 * 0,89+0,9 * 1,33+0,8 * 0,49+0,9 * 0,91+1 * 0,85+0,9 * 0,47=4,6 .
$$

The overall assessment of the competitiveness of rural areas in the Rostov region is characterized as high. However, the calculated level of 4.6 does not fully correspond to the ideal value from the point of view of public administration and consumers. Our calculations correspond to the research of scientists of the A. A. Nikonov VIAPI, who compiled a rating of regions for the quality of life of the rural population, according to which the Rostov region entered the top ten regions with the highest indicators of the quality of life of villagers with an overall rating score of 59.9 against 68.6 for the leader - the Lipetsk region.

The overall level of competitiveness of rural areas in the Rostov region is positively affected by the cost of agricultural production per 1 person, a high share of exports, which is 3 times higher than the value for the Krasnodar territory, the share of the working-age population in rural areas compared to the average in Russia, and the life expectancy of the rural population, which exceeds the target value set for 2018 .

The overall level of economic development of rural areas in the region in 2018 can be described as high: the gross agricultural output per capita of the rural population amounted to 189.1 thousand rubles, which is almost $25 \%$ higher than the value for the Krasnodar territory. At the same time, the salary of agricultural workers in the Rostov region in 2018 was $7.3 \%$ lower than the average value in Russia (26,589.7 rubles against 28,699. 0 rubles).

The main indicators that reduce the level of competitiveness of rural areas in the region 
are low innovative activity of agricultural enterprises, high unemployment in rural areas, the share of specialists with higher education, and the state of the environment.

In 2018, only 149.0 million rubles were spent on technological innovations by the type of economic activity "Agriculture".

The main problem in rural areas remains unemployment, which is almost twice as high as in urban areas. Lack of work affects the quality of personnel in agricultural production only $52.4 \%$ of managers and specialists have higher education, while $4.3 \%$ of workers in mass professions have higher education.

Qualified employees prefer to find jobs in organizations in more profitable sectors of the real economy. The lack of qualified personnel can become a real obstacle to the introduction of innovations in agricultural production [15]. Moreover, the personnel shortage is also typical for the non-agricultural sector - there is a shortage of teachers and medical personnel in the villages. Activities of the national projects "Education" and "health" are also aimed at solving this problem.

In the Rostov region, there is an unstable situation in terms of environmental indicators: a high value in the indicator of degradation of agricultural land from water and wind erosion, a low share of equipment of industrial enterprises with technological installations for capturing and cleaning the extracted air. In 2018, 1914 atmospheric air samples were examined in rural localities. in comparison with 2014, the share of atmospheric air samples that do not meet hygiene standards increased and amounted to $2.45 \%$ against $1.9 \%$ in 2014 .

The improvement of the social environment and the development of agricultural production, which is a strategic object of rural life and the basis of the economic and environmental well-being of the local population, which is the basis for overcoming the crisis phenomena in the economy, will contribute to the growth of the competitiveness of rural territories.

\section{Conclusion}

When assessing the competitiveness of rural areas, it is necessary to follow the principle that the reproduction of human capital and the socio-cultural environment should occur at a faster rate than the reproduction of their economic potential.

This research method allows us to calculate the level of competitiveness of rural territories not only in dynamics over the years to identify the impact of factors acting on the indicator, but also to conduct a comparative characteristic in the regional aspect. This approach will help identify regions that need support and rural areas that can be used as a model for regional development.

Modern conditions that require improving the quality of life of the population, transition to sustainable development, the formation of competitive advantages of the territory in the context of slowing economic growth, transitive processes in the socio-economic system and the manifestation of new qualities of the global environment pose the task of further analyzing the state and assessing the prospects for moving along the trajectory of sustainable development of rural territories. At the same time, the development of agricultural production is the basis, the most important component of the integrated development of rural territories and the state as a whole, determining the effectiveness of the socio-economic system, forming its resistance to destructive processes and new world transformations.

\section{References}

1. J. D. van der Ploeg, Sociologia Ruralis, 40(4), 497-511 (2000) 
2. A. Kostyaev, Economics of Agriculture of Russia, 10, 88-103 (2018) doi: 10.32651/2070-0288-2018-10-88-103

3. V. Pertsev, Sustainable development of rural territories of the municipal district: dis. Cand. Econ. sciences' (Voronezh, 2011)

4. T. Nikitina, Bulletin of the Kursk state agricultural Academy, 4, 106-112 (2019)

5. S. Semenov, V. Rubtsova, Scientific review: theory and practice, 10(6), 1150-1170 (2020) doi: 10.35679 / 2226-0226-2020-10-6-1150-1170.

6. R. Yanbykh, V. Saraikin, Z. Lerman, Russian Journal of Economics, 6(1), 26-41 (2020) doi: https://rujec.org/article/49746/

7. A. Tarasov, S. Shchitov, A. Petkova, Models of economic forecasting of Russian agriculture development in the context of global challenges: Monogr., FGBNU " Vseros. scientific research. Institute of Economics and standards". Rostov n/A: LLC "Azovprint", 108 (2017)

8. Federal state statistics service of the Russian Federation-URL: https://www.gks.ru/ (Last accessed 21.05.2020)

9. O. Shik, Russian Journal of Economics, 6(1), 42-55 (2020) doi: https://doi.org/10.32609/j.ruje.6.49756

10. W. Liefert, O. Liefert, Russian Journal of Economics, 6(1), 56-70 (2020) doi: https://doi.org/10.32609/j.ruje.6.50308

11. O. Shakhbazova, R. Radzhabov, A. Kolosov, Development of information technologies for the development of the agricultural economy in the context of import substitution and global challenges, 159 (Persianovsky, 2018)

12. V. Tarasov, V. Ershov, E. Abrashkina, Economics of Agriculture of Russia, 7, 2426 (2020) doi: 10.32651/207-24

13. A. Tarasov, N. Antonova, A. Tarasov, S. Podgorskaya, etc., Cognitive modeling in the management of rural development: monograph - Rostov Vniiein-branch of the Federal state budgetary INSTITUTION FRANTZ: Publishing house of LLC "Azovprint", 128 (2019)

14. Report on the state and use of agricultural land in the Russian Federation in 2018, 340 (Moscow, fgbnu "Rosinformagrotech", 2020)

15. S. Podgorskaya, Improving the human resources potential of rural territories as the basis for their sustainable development. Agriculture of Russia and abroad: modern challenges of economic development: Materials of the international scientific and practical conference. All-Russian research Institute of Economics and standards, branch of FEDERAL state budgetary FRANZ, 336-341 (2018) 